\title{
China's Belt and Road Initiative Extension to Central and Eastern European Countries - Sixteen Nations, Five Summits, Many Challenges
}

Marsela Musabelliu

\section{Abstract}

The Belt and Road Initiative proclaimed by President Xi in 2013, a strategy developed by the Chinese government, is very important to China but is not confined to China. In order for the initiative to be successful it needs to be embraced by the countries on the terrestrial and maritime route indicated in the plan. In the late 1980s Deng Xiaoping proposed to integrate Socialism with Chinese Characteristics (Zhongguo Tese Shehui Zhuyi, 中「特色社「主「) into global capitalism and in the 1990s the Jiang Zemin leadership initiated the Going out policy (Zouchuqu Zhanlue, 走出去「略) - the current Belt and Road Initiative is China's continuation in implementing those policies into actual deeds. China's accession to WTO in 2001 marked China's full integration into the global economy and since then the People's Republic of China (PRC) has become the largest trading partner for more than 180 countries. The Xi-Li administration has been extremely proactive since it was established in 2012; from that year on, Chinese behavior in international affairs has gained an ever-growing role as a forger of economic and diplomatic ties between countries. The primary example of this behavior is the Belt and Road Initiative (BRI). As every serious foreign policy plan, the BRI is an accumulation of various other initiatives. For example, the cooperation mechanism " $16+7$ ", with which the PRC has approached Central and Eastern European Countries (CEEC), can be integrated under the BRI. This paper analizes the "16+1" China-CEEC cooperation mechanism in the context of the bigger BRI initiative, and tries to comprehend the economic and political factors intertwined with its implementation.

\section{KEY WORDS:}

Belt and Road Initiative, China, CEEC, economic cooperation, challenges 


\section{Introduction: The Belt and Road Initiative (yi dai, yi}

lu - 带一路)

China's new Belt and Road Initiative is trying to reimagine the ancient Silk Road trading routes by connecting East and West over land and sea. For over 1600 years the Silk Road promoted the exchange of Western and Eastern civilizations, bringing together Chinese, Indians, Persians, Arabs, Greeks and Romans. This initiative highlights the core of China's new strategic development, founded on economic progress and shared prosperity. Clover and Hornby (FT Analysis 2015), estimate that, "[...] if the sums of total commitments are taken into account, the BRI is set to become the largest program of economic diplomacy since the US-led Marshall Plan for postwar reconstruction in Europe, covering dozens of countries with a total population of over three billion people". What is happening is that Beijing functionaries are trying to inject new vitality to these ancient trading routes through a new economic master plan that would connect Asia, Europe and Africa with one single development policy, financially supported by one institution, the Asian Infrastructure Investment Bank (AIIB). The Chinese government, through a National Development and Reform Commission (NDRC News Release 2015), advocates "[p] eace and cooperation, openness and inclusiveness, mutual learning and mutual benefit as the benefits of the BRI... By promoting practical cooperation in all fields and will work to build a community of shared interests, destiny and responsibility featuring mutual political trust, economic integration and cultural inclusiveness". This Chinese vision seeks to replicate and expand the results of the Asian Miracle. The economic takeoff of East Asia consolidated domestic stability in most countries; Likewise, regional peace dramatically improved as countries realized that a focus on economic growth would bring more stability (Overholt 2015).

However, CEEC and Asia are two very different realities and identifying how the BRI can function in a non-Asian land becomes essential. The necessity here is to determine which are the channels and modus operandi of the BRI, and how it can actually be implemented in a given group of states through the 
regional approach. The main purpose of this paper is to analyze and understand this specific cooperation mechanism between CCEC and China, in three different perspectives: first, by analyzing leadership discourse and policymaking; second, by considering the 16 nations of CEEC as distinct economic and social entities and third, by understanding the significance of high level political summits and how much they actually impact upon a project's implementation.

The keyword for BRI seems to be infrastructure. The Chinese authorities see infrastructure (with the outcome of facilitating transportation) as the milestone for what will be the Eurasian "Economic Corridor".

\section{Xi Jinping: the man with a dream and plan}

In order to better understand the BRI's impact outside China, it is essential to seek an organizing principle in terms of the PRC's overall foreign policy objectives. For this it is important to know the "fifth generation of Chinese leaders", guided by Xi Jinping.

Soon after becoming the leader of the Chinese Communist Party in 2012, he introduced what would become the blueprint of his foreign policy. The Chinese Dream, he said, is the great rejuvenation of the Chinese nation; Xi's Chinese Dream is portrayed as accomplishing the "Two 100s". ${ }^{2}$ From that year on, with the shift of power in Chinese leadership, we see a very proactive attitude in foreign affairs. President Xi and premier Li are perhaps the Chinese leaders with the most foreign visits in the last three decades. President's Xi Chinese dream seeks to combine national and personal aspirations to reclaim national pride and enhance personal well-being;

1 Five generations of Chinese leaders after the proclamation of the People's Republic of China starts with Chairman Mao Zedong as leader, followed by Deng Xiaoping, Jiang Zemin, Hu Jintao, and the fifth, Xi Jinping.

2 1) The material objective of turning China into a "respectably well-off society" by 2021, the 100th commemoration of the Chinese Communist Party, and 2) The modernization objective of turning China into a fully developed country by around 2049, the 100th commemoration of the establishing of the People's Republic of China 
China's foreign policy was not equally dynamic in the past. In this regard, making a comparison with the previous leader, Ferdinand (2016: 941), states "Hu Jintao was extremely risk-averse and largely preoccupied with maintaining domestic economic growth."

It is President Xi's plan to associate Asia and Europe by putting resources into framework activities to improve exchange and social relations. These activities are upheld by unfathomable money related assets, such as the AllB fund (more than 100 billion US dollars), the New Development Bank (NBD) and the Silk Road Fund.

The first time the world heard about this initiative was in Kazakhstan, during a visit of President $X_{i}$ in the country. He states:

"Shaanxi, my home province is the starting point of the Silk Road. As I stand here I reflect on history, I can almost hear the camel bells echoing among the mountains and see the wisp of smoke rising from the desert. It all reminds me of home... throughout the millennia, the peoples of various countries along the Silk Road have jointly reached a chapter of friendship that has been passed on this very day..." (Ministry of Foreign Affairs of the People's Republic of China 2013$)^{3}$

From the above we can see that this initiative is the tool of a foreign policy master plan as much as it is a personal endeavor and challenge for the Chinese President. Xi starts by evoking the past, while tracing the guidelines for the future cooperation of the countries involved in the initiative. Kissinger (2014) argues that the rise of China into eminence in the $21^{\text {st }}$ century is not new but it reestablishes historic patterns. What is distinct is that China has returned as both the inheritor of an ancient civilization and as a contemporary great power in the Westphalian model. It combines the legacies of all under heaven, technocratic modernization and an unusually turbulent $20^{\text {th }}$ century quest for a synthesis between the two.

3 President $\mathrm{Xi}$ chose a foreign, neighboring country to launch his new initiative, in the most exclusive academic environment of Kazakhstan: Nazarbayev University, in Astana. 


\section{Pragmatism in action - what's in it for China?}

Chi (2015: 54) considers that "the implementation of the New Silk Road strategy will unleash a regional infrastructure boom by connecting China with Asia, Europe, and Africa by land and sea, and boost RenMinBi (RMB) internationalization by encouraging its use in both trade and financial transactions. Domestically, it will help export China's excess capacity, which should enhance investment returns and stabilize growth... Beijing is using the project to secure foreign trade relationships in response to some major trade pacts that have excluded China in the past". The proclaimed Beijing consideration on the initiative, among others, is: "...to forge closer economic ties, deepen cooperation and expand development in the Euro-Asia region... take an innovative approach and jointly build an 'economic belt' along the Silk Road" (See: Ministry of Foreign Affairs of the People's Republic of China 2013.).

Chi continues by highlighting also that "the initiative has three main pillars: first, spreading economic development around the world through infrastructure investment and new trade routes; second, creating interdependence between China and other countries and regions via global partnership networks; and third, focusing on Asia as part of a new "neighborhood diplomacy" strategy. By building closer economic ties with the regional economies along the New Silk Road premier Xi promises to meet the expectations of history and the Chinese people" (Chi 2015: 56).

\section{China-CEEC partnership framework}

According to Xi (2006: 47), geostrategic policymaking "represents a country's effort in the world arena to use geographic orientation and principles to pursue and safeguard its national interests. Entering the twenty-first century, China's geostrategic relationships 
(2) andergoing profound change".

Chinese presence and initiatives in Central and Eastern Europe are not new. The first step for an East European alliance between Romania, Yugoslavia and Albania, was made by Prime Minister Zhou En Lai in 1968. ${ }^{4}$ During the Cold War, Chinese foreign policy officials had already made their advances in these three countries. This was the first time that China was engaged in energetic behavior towards Europe. Chinese policy makers intended to create a strong regional fulcrum under Beijing's influence, for their future interest in the European market. However, the plan was never implemented. The late 1980s and early 1990s were years of great social and political changes in both areas under examination. After the fall of the Berlin Wall, both China and CEEC countries, faced challenges of transformation and transition. While the PRC took a gradual approach to reforms the CEEC countries went for drastic reform strategies and immediate opening to the outside world.

As mentioned earlier, the countries under analysis in this paper are part of a cooperation mechanism named " $16+1$ ", which is the cooperation between 16 Central and Eastern European Countries plus the People's Republic of China. The 16 countries of the CEEC include: the three Baltic countries of Estonia, Latvia and Lithuania; the four Central European countries of Poland, Hungary, the Czech Republic and Slovakia, also known as Višegrad countries; the nine Eastern and Southeast European nations of Albania, Bosnia and Herzegovina, Macedonia, Croatia, Montenegro, Bulgaria, Slovenia, Serbia and Romania, namely the Balkans. In order to gain a better geographic understanding of these nations let us turn to the memorable speech of Winston Churchill in 1946, who claimed that an "Iron Curtain" was being formed in the heart of Europe between East and West, in essence all CEEC countries are what Churchill placed on the eastern side of the Curtain. These countries seem somehow similar in their political past, especially during the Cold War, but have plenty of dissimilarities after the 1990s in economic, social, and foreign policy discourse.

4 It was easier for the Chinese premier to place Romania and Yugoslaviain the same alliance, as both of these countries had turned away from Moscow and had no conflict, past or present, with each other. Premier Zhou knew that the hardest party to convince for this possible future alliance would have been Albania. 
Returning to economic and social differences between the CEEC, we will now inspect some important statistical indicators:

Table 1: CEEC general and governmental performance indicators

\begin{tabular}{|l|r|r|r|r|r|r|}
\hline Country Name & $\begin{array}{r}\text { Population } \\
\text { in millions }\end{array}$ & $\begin{array}{c}\text { GDP in } \\
\text { Billions of } \\
\text { USD }\end{array}$ & $\begin{array}{r}\text { GDP } \\
\text { growth in } \\
\%\end{array}$ & $\begin{array}{r}\text { Per capita } \\
\text { GDP } \\
\text { thousands of } \\
\text { USD }\end{array}$ & $\begin{array}{r}\text { Unemploy } \\
\text { ment, total } \\
\text { (\% of total } \\
\text { labor } \\
\text { force) }\end{array}$ & $\begin{array}{c}\text { GINI } \\
\text { index * } \\
2012\end{array}$ \\
\hline Albania & 2.89 & 11.46 & 2.6 & 3,965 & 16.10 & 28.96 \\
\hline Macedonia, FYR & 2.08 & 10.09 & 3.7 & 4,853 & 27.90 & $\ldots$ \\
\hline Montenegro & 0.62 & 3.99 & 3.4 & 6,415 & 19.10 & 32.18 \\
\hline Bulgaria & 7.18 & 48.95 & 3.0 & 6,820 & 11.60 & 36.01 \\
\hline Bosnia and Herzegovina & 3.81 & 16.00 & 3.2 & 4,198 & 27.90 &.. \\
\hline Croatia & 4.22 & 48.73 & 1.6 & 11,536 & 16.70 & 32.51 \\
\hline Serbia & 7.10 & 36.51 & 0.7 & 5,144 & 22.20 & \\
\hline Romania & 19.83 & 177.95 & 3.7 & 8,973 & 7.00 & 34.88 \\
\hline Hungary & 9.84 & 120.69 & 2.9 & 12,259 & 7.80 & 30.55 \\
\hline Slovenia & 2.06 & 42.75 & 2.9 & 20,713 & 9.50 & 25.59 \\
\hline Slovak Republic & 5.42 & 86.58 & 3.6 & 15,963 & 13.30 & 26.12 \\
\hline Czech Republic & 10.55 & 181.81 & 4.2 & 17,231 & 6.20 & 26.13 \\
\hline Poland & 38.00 & 474.78 & 3.6 & 12,494 & 9.20 & 32.39 \\
\hline Lithuania & 2.91 & 41.24 & 1.6 & 14,172 & 11.30 & 35.15 \\
\hline Latvia & 1.98 & 27.04 & 1.9 & 13,665 & 10.00 & 35.48 \\
\hline Estonia & 1.31 & 22.69 & 1.1 & 17,295 & 7.70 & 33.15 \\
\hline
\end{tabular}

As we can see from Table 1, we are dealing with a group of countries with relatively small populations, except Poland and Romania. Considering the total GDP of each of the CEEC, these are small scale economies and some almost medium ones. The economic performance of the CEEC is diverse, led by the Czech Republic with growth of $4.2 \%$ and trailed by Serbia with $0.7 \%$ growth. According to the latest statistics the average unemployment of the Eurozone is around $10 \%$, and according to mainstream economics scholars any country with more than a $15 \%$ unemployment rate is not performing well (Eurostat Statistics Explained, 2016). As we can see six out of the sixteen CEEC are definitely not in good shape with regards to their labor market. The GINI index (See: World Bank, 2016?) demonstrates that the countries under analysis have still a huge gap in their population between rich and poor. 


\begin{tabular}{|l|r|r|r|r|r|c|}
\hline Country Name & $\begin{array}{c}\text { Ease of } \\
\text { doing } \\
\text { business } \\
\text { index (1) } \\
\text { o190) }\end{array}$ & $\begin{array}{c}\text { Imports of } \\
\text { goods and } \\
\text { services } \\
\text { (current } \\
\text { millions } \\
\text { US\$\$) }\end{array}$ & $\begin{array}{c}\text { Exports } \\
\text { of goods } \\
\text { and } \\
\text { services } \\
\text { (current } \\
\text { millions } \\
\text { US\$\$) }\end{array}$ & $\begin{array}{c}\text { Foreign direct } \\
\text { investment, } \\
\text { net inflows } \\
\text { (BoP, current } \\
\text { US\$ millions) }\end{array}$ & $\begin{array}{c}\text { Inflation, } \\
\text { consumer } \\
\text { prices(\% } \\
\text { annual) }\end{array}$ & $\begin{array}{c}\text { Total } \\
\text { natural } \\
\text { resources } \\
\text { rents } \\
\text { of GDP) }\end{array}$ \\
\hline Albania & 90 & 5.07 & 3.11 & 981.50 & 1.89 & 5.40 \\
\hline Macedonia, FYR & 16 & 6.54 & 4.89 & 192.65 & -0.30 & 3.06 \\
\hline Montenegro & 48 & 2.44 & 1.73 & 699.74 & 1.55 & 0.71 \\
\hline Bulgaria & 37 & 31.83 & 32.54 & $1,773.86$ & -0.10 & 1.87 \\
\hline Bosnia and Herzegovina & 79 & 10.54 & 6.28 & 267.28 &.- & 1.49 \\
\hline Croatia & 39 & 22.73 & 24.06 & 158.97 & -0.46 & 1.68 \\
\hline Serbia & 54 & 20.97 & 17.41 & $2,345.15$ & 1.39 & 3.03 \\
\hline Romania & 35 & 74.06 & 73.13 & $3,890.53$ & -0.59 & 1.69 \\
\hline Hungary & 40 & 113.43 & 123.48 & -966.57 & -0.07 & 0.47 \\
\hline Slovenia & 30 & 29.27 & 33.27 & $1,680.44$ & -0.52 & 0.50 \\
\hline Slovak Republic & 30 & 79.11 & 81.21 & $2,149.68$ & -0.33 & 0.54 \\
\hline Czech Republic & 26 & 141.91 & 153.60 & $2,478.53$ & 0.34 & 0.44 \\
\hline Poland & 25 & 221.11 & 234.36 & $7,353.00$ & -0.99 & 1.44 \\
\hline Lithuania & 21 & 31.93 & 31.88 & 627.35 & -0.88 & 1.18 \\
\hline Latvia & 17 & 16.27 & 15.89 & 719.04 & 0.20 & 2.56 \\
\hline Estonia & 11 & 17.17 & 18.10 & -174.21 & -0.46 & 2.71 \\
\hline
\end{tabular}

Regarding the business and trade environment of the CEEC there are still uncertainties and different levels of performance amongst the group. For example, the ease of doing business (The World Bank, 2016?).varies hugely, with the most business friendly being Estonia and the least, Albania. Regarding exports and imports (for both, services and goods) the total volume goes mainly according to population, the larger the population the higher this index. In terms of FDI the most attractive are Poland and Romania, and the least attractive are the FYROM and Montenegro. Regarding consumer prices we see 10 countries with deflation of those prices and five with low inflation percentages. And last, Table 2 shows us that the natural resources of all of those countries show very little contribution to their overall economic performance.

\section{Cooperation Mechanism of " $16+1$ " and the pivot on investments}

This political and economic partnership is quite peculiar, no aggregation, international network or association could embody the same aspects as the "16+1". Institutionally everything started in April 2011 when Wen 
Jiaobao visited Eastern Europe, starting from Poland. The next step of cooperation was to call yearly summits where all leaders would meet in a joint session and after that, if representatives desired, meetings would proceed to bilateral talks.

The first China CEEC Summit was held in Warsaw in 2012, and had emblematic significance since the prime ministers of these countries had never before been all gathered in the same venue.

Usually all Heads of States and decision-making personalities are present at these summits (Prime Ministers, Ministers of Trade, Minsters of Infrastructure, etc.).The most important outcome of this summit was "China's Twelve Measures for Promoting Friendly Cooperation with Central and Eastern European Countries". According to the documents from the official release (MFAPRC News Release 2012), the main points included "... the creation of a Secretariat for Cooperation between China and CEEC; the establishment a US $\$ 10$ billion special credit line with focus on infrastructure; China committed to send trade and investment promotion missions to the 16 countries involved in the process". Further, the Chinese government promised to provide 5000 scholarships for students of these countries in order for them to study in the PRC; a forum on cultural cooperation would be held and a tourism promotion alliance would be established. In addition, premier Wen Jiabao introduced a four-point proposal on promoting and deepening relations within the " $16+1$ " platform by focusing on establishing a perfect working mechanism, exchange platforms of cooperation, specify priorities of cooperation and enhance closer cultural and people-to-people exchange. Politically, the most important pronouncement of premier Wen was: "Chinese leaders hope that the two sides will make joint efforts to inject new vitality on the development of China-Europe relations". Essentially, the hidden message here (confirmed in a formal declaration two years later) is that the " $16+1$ " is an integral part of China-EU cooperation, and not an isolated foreign policy strategy oriented only towards these 16 countries. On the other hand, declarations from CEEC representatives welcomed and applauded China's contribution to the global economy and its fast economic growth was portrayed as a successful model of development.

The second China-CEEC summit was held in Bucharest in 2013. At 
this time China's political establishment had changed and the representative who visited Romania was Premier Li Keqiang. His main analysis was the untapped potential of CEEC which in 2013 represented only $1 / 10$ of China-EU trade volume. Much more could be done since China was willing to further promote trade and investment in the region. In order to further expand cooperation and limit protectionism from all sides, the guidelines of the summit pledged to hold a number of events including: a China-CEEC ministerial meeting; an expo of CEEC commodities in China; a symposium on investment promotion, as well as support the establishment of the association of chambers of commerce. During this summit China achieved an agreement with Hungary and Serbia to together construct a railroad between these two countries, within the Chinese investment framework for the region. As in the previous summit, as far as investments were concerned the headline was again infrastructure.

The third summit was held in Belgrade in 2014 and the theme of was: "New Driving Force, New Platform and New Engine". All parties involved, while reaffirming their commitment to deepening their partnership, expressed the need to formulate a medium term agenda on account of project implementation and continuation. And again, the highlight was to enhance cooperation and connectivity, but this time besides infrastructure many other fields of common interest were highlighted, for example: the promotion of Small and Medium Enterprises (SME); signing currency swap agreements; developing nuclear energy projects and promoting sustainable use of natural resources;

In fact, some of the most important points of the joint declaration after the summit (MFAPRC News Release 2014), was to "strengthen the cooperation in infrastructure development, such as construction of roads, railway, ports and airports on the principle of mutual benefit; creating an investment fund of US $\$ 3$ billion in order to facilitate financing procedures in the CEEC and expand cooperation in science, technology, innovation, environmental protection; establishing of the China-CEEC Think Tanks Exchange and Cooperation Center". The Ministry of Foreign Affairs of the People's Republic of China, as the comprehensive coordinating institution for China-CEEC cooperation, would actively support the Chinese Academy of Social Sciences (CASS) for this purpose. 
At the start of the fourth summit in Suzhou in 2015, Premier Li Keqiang (CNON Opinion 2015) stated: "Over the past three years, ' $16+1$ ' cooperation, just like a high-speed train, has set out on its journey and gained speed all the way from Warsaw to Bucharest and from Belgrade to Suzhou". This is a very important step in publicly integrating the " $16+1$ " in the frame of the BRI and what Chinese scholars name "Mr. Li's Railway Diplomacy".

The motif of this summit was: "A New Beginning, New Domains, and A New Vision". These three new perspectives speak to a plan for collaboration for the coming five years and six agreed upon priorities: actualizing a guide for propelling participation; improving synergy between the BRI and policymaking within the CEEC; searching for better approaches to finance cooperation; enhancing people-to-people cultural and personal exchange; intensified cooperation in the spheres of agriculture and forestry; beginning cooperation on the local government level. The Medium Term Agenda mentioned in the Belgrade Guidelines one year earlier were also highlighted in Suzhou. Most importantly, the idea that the "16+1" framework for cooperation in embedded in the China-EU Strategic Agenda Cooperation was reemphasized as highlighted by the addition to the Suzhou Guidelines (MFAPRC News Release 2015), which states: "This cooperation will aim to advance important national and regional projects. Instead of replacing existing bilateral cooperation mechanisms or platforms, "16+1" strives to complement and reinforce them, aiming at enhanced and expanded cooperation between China and the 16 countries".

The main theme of the fifth summit, held in Riga, was: "Three Seas Interconnectivity". The summit (MCPRC News Release 2016) aspired "... to strengthen Adriatic-Baltic-Black Sea Seaport Cooperation, in line with the geographical distribution of ports and their future development needs. This increased cooperation is to be achieved by: better using, developing, and upgrading ports; supporting cooperation in ports investments; expanding the handling capacity of ports and extending the shipping route network of the three seas and inland waterways and ports". China claimed to be ready to build industrial and technological parks with the CEEC, conduct cooperation on deep processing of agricultural products, and help these countries raise their level of industrialization and agricultural productivity. The "16+1" financial holding company proposed 
the previous year in Suzhou was officially established. Led by the Industrial and Commercial Bank of China, the holding company is expected to raise funds from global markets through commercial operations. Five principles of cooperation were also agreed upon: 1) equality, mutual respect and mutual assistance; 2) mutual benefit and win-win cooperation; 3) openness and inclusiveness; 4) interconnected development; 5) joint contribution and shared benefits. It is important to note that at this summit participants (special envoys) from EU, Austria, Switzerland, Greece, Belarus and the European Bank for Reconstruction and Development, were present as observers.

Besides the direct link of this cooperation with the BRI (which is a long-term foreign policy plan), internal development in the PRC's establishment and institutions should not be overlooked. "The goals of China's direct investments in Central and Eastern Europe should be viewed in the wider context of the development goals identified in the CCP twelfth Five-Year Plan for the years 2011-2015. The Plan mentions the need to acquire strategic assets to: enable Chinese companies to increase their competitiveness in global markets; increase investments in foreign infrastructural projects; offer preferential loans for projects carried out by Chinese contractors" (Jakobowski 2015: 2).

From the abovementioned activities we can see that the plan is no longer conceptual, but implementation has already started and has progressed with significant steps.

\section{Challenges of cooperation}

This diversity of views about the implications of China's rise in global politics is testimony to the uncertainty associated with that rise. But one aspect is abiding: As Shambaugh (2013: 317) states, "China going global will undoubtedly be the most significant development in international relations in the years ahead. Since China's opening to the world in 1978, the world has changed China - and now China is beginning to change 
the world". A lot has been written on the challenges that the BRI could face in its implementation and the same can be said for its extension, the " $16+1$ " cooperation platform. In any cooperation plan where a lot of countries are involved, difficulties are inevitable.

\section{Internal challenges}

First and foremost, the different stages of development for each of the CEEC could slow down the development of projects. There are differences in the structure of the CEEC economies, the division of the group into EU and non-EU states, into nations which are part of the Eurozone and those who are not. This makes it difficult to devise a uniform approach towards the countries under analysis. It must also be underlined that the 16 nations do not shape a single coalition and they sometimes see each-other as opponents and, to some degree, they struggle with who and how will earn the most out of the flow of Chinese investments towards the region (Turcsanyi 2014). As a consequence, coordination within the group is lacking. The most successful investment for now has been the Hungary-Serbia railway, in which both countries showed economic and political maturity in developing the project funded with Chinese money; but for the remaining countries there is still a long way to go.

The next internal challenges are the governments of some of the countries involved in the cooperation mechanism. Especially in the Balkan Peninsula, most of them are "fragile democracies", not more than 30 years old. Transitioning from one governance system to another is never without consequences. Such states suffer social instability, financial fluctuations, institutional fragility and last but not least, corruption. Antagonism between Balkan countries is another issue. Perhaps it is not an existential threat to the cooperation mechanism, but let us not forget that 17 years ago there were actual armed conflicts in the region and the repercussions of these conflicts are still unfolding in the region. 


\section{External challenges}

The Chinese official standpoint is that of including the China-CEEC relations under the China-EU framework and cooperation structure. We must highlight here that eleven countries within the "16+1" mechanism are members of the EU, and three of them are founding members. ${ }^{5}$ Long (2014), argues that "the EU takes a suspicious and cautious attitude to the establishment and development of the China-CEEC cooperation mechanism. The EU is concerned that China is trying to achieve a political objective in dividing the EU countries through economic means, and regrouping EU states according to their attitudes towards China. Such a strategy would weaken the appeal of Brussels and prevent its consistency in foreign policy". Another important factor to consider in this agenda is Russia. No tangible declarations by Russian politicians have been made about the "16+1", but while dealing with the individual parties, China and CEEC, Russia seems to be very cautious. Most of the countries which are part of the CEEC have a long history with Russia, notable many were satellites of the Soviet Union, and most of them experience economic dependence on Russian gas as an ever-present factor in foreign policy decision making.

From the other side of the Atlantic, the other major actor is the United States of America (USA). The dominant insecurities coming from the USA are security threats, as 12 countries out of 16 are NATO members. ${ }^{6}$ So far no official statement has been released from Washington, but this does not mean that the cooperation initiative has been overlooked. International relations at the beginning of the 21 st century are marked by the most important bilateral relationship in the world, that between China and the US. Some scholars (eg. Kissinger 2011; Shambaugh 2013; Zhang 2012; Friedberg 2011) firmly believe that this relationship will define the current century, and getting this relationship right is essential for global peace and stability. The two states closely analyze every move of the other and, of course, any possible new alliance with other nations. In his new book World Order, Kissinger (2014) describes China as 'Conceptual' and the

5 The Baltic States: Estonia, Latvia and Lithuania.

6 In chronologic order of accession to NATO: Czech Republic, Hungary, Poland (1999); Bulgaria, Estonia, Latvia, Lithuania, Romania, Slovakia, Slovenia (2004); Albania, Croatia (2009). 
United States as 'Pragmatic'; we will have to see in the next years if his assessments of these countries will also apply to the "16+1" cooperation mechanism.

A further discontent is circulated about the absence of long term clarity of deals and plans as well as the possible undermining of the market potential of European companies and organizations. Casarini (2015: 9) claims that "infrastructure works financed by China's soft loans are carried out by Chinese companies, as in the case of the Hungary-Serbian high-speed railway or Terminal II of Piraeus. This raises the question of reciprocity. While Chinese companies find an open-door environment in Europe, it is quite difficult, if not impossible, for a European company to succeed in winning a contract to build an infrastructure project in mainland China".

Finally, besides the official and unofficial discourse from outside the "16+1", the primary issue is that of influence. What are we to expect from the PRC? What is the PRC's agenda and ulterior motives? For Poulain (2011: 6-7), "Beijing's sizeable investments in CEEC are as much about financial returns as they could be about leverage. The investments by Chinese state-owned companies on the periphery of the EU, have not only given China an indirect say in European affairs, they have also signaled to the U.S. and the West that Beijing is ready to advance its own agenda in the region."

The term "mutual distrust' is often used in describing the China-US political relationship, however we might see it more often used in the future to describe China-EU relations. Le Chorre and Sepulchre (2016) name an entire chapter of their book 'Spreading the tentacles, opportunistically' referring to the Chinese investments in Europe. They argue that the evergrowing Chinese presence in Europe is working to expand Beijing's power through finance and infrastructure.

The challenges go both ways. Since its creation in 1993, the EU has continued to provide one of China's most visible multilateral challenges. Beijing has had to adjust its European policies to take into account both Union and country-level decision-making procedures, further complicated by the lack of single cohesive EU foreign and often economic policy (Lanteigne 2013: 144). 
Many seem concerned about what is not proclaimed in the plan; which is the final aim of this terrestrial expansion throughout the Belt and Road countries. What the skeptics fail to admit is that securing economic growth is at the core of national security policy proclaimed from Beijing and to further ease worries, President Xi has emphasized the "Three No's" policy within the BRI: China will not interfere in the internal affairs of the nations along the BRI route; will not try to increase its influence towards these nations; and last but not least, PRC is not striving for hegemony or dominance.

\section{Conclusions}

China's ascent as an important factor in the international arena is the most essential aspect of what some scholars (eg. Tselichtchev 2012; Rosefilde 2013) name the "Global Power Shift of the 21 st Century".

The Chinese "economic miracle", its GDP growth in double digits after the 2000s, the lifting of hundreds of millions out of poverty in just two decades, can be ascribed to a slow and gradual reformation of the country's core policy, a proper transition from a centrally planned economy to a free market one, and opening to the outside world as perhaps a new forger of globalization. These factors, and more, make the PRC a desirable partner in the economic field.

The CEEC, experiencing the heat of the financial crisis of 2008, turned to China in search of investments, financial cooperation and new trade agreements. CEEC location favors these moves since their geographic position between East and West can easily provide a connection between the markets of Asia and Europe, which could give the area enormous potential to end up as a key point for direct exchange between the two continents.

Although China is much larger than Central and Eastern European countries in term of area, population and the size of its economy, China 
has sought to build partnership with the CEEC on an equal footing. The " $16+1$ " cooperation framework, in which each country is an equal partner, can serve as the platform to enhance every country's interests. The China-CEEC summits bear compelling significance in their origin and operation. They not only express the seriousness with which Beijing is dealing with the situation but also the meeting schedule demonstrates the commitment of the parties involved.

The Chinese behavior in the CEEC group should be viewed as both pragmatic and proactive. Chinese behavior was proactive because it was the PRC who initiated the entire process of cooperation, and pragmatic because the emphasis is always on win-win cooperation and easy access to trade and investments. However, this cooperation faces many challenges, inwards and outwards the same mechanism.

In a situation where 16 nation states of Central and Eastern Europe with individual historical, social and economic backgrounds meet and schedule a cooperation mechanism with a "civilization state" such as China, progress is not always smooth. Even in the very short lifespan of only a few years, the " $16+1$ " platform has triggered reluctance, concerns and sometimes discontent, both within and outside the group.

Even though regionally-led implementation of projects is less expensive and moves at a faster pace than traditional technical assistance from a global perspective, in order for China-CEEC cooperation to properly function every aspect of participation should be conducted through policy communication and the coordination of objectives.

While analyzing Chinese behavior in the region one point is vital: commercial exchange. Every diplomatic, political and economic approach the PRC has towards the region is just an extension of Beijing's actual foreign policy: cooperation through mutual benefit and progress.

Last but not least, let us remind ourselves that the BRI makes China the only country in the world today with a clear long term plan for the rise of the global economy. 


\section{B Bibliography}

Casarini, N., 2015. Is Europe to Benefit from China's Belt and Road Initiative? Insituto di Affari Internazionali, IAI - Working Papers, 15(40): 1-11.

Chi, L., 2015. China's Silk Road Strategy. The International Economy, 29(4): 54-75.

Clover, C. and Hornby, L., 2015. China's Great Game: Road to a new empire. A modern Silk Road is Beijing's signature foreign policy. Financial Times, [online] October. Available at:https://www.ft.com/content/6e098274587a-1 1e5-a28b-50226830d644 [Accessed 25 October 2015].

CNON Opinion, 2015. China National On-Line News. [online]. Available at: http://www.china.org.cn/opinion/2015-12/11/content_37291453. htm [Accessed 10 August 2016].

Eurostat Statistics Explained, 2016. Available at: http://ec.europa.eu/ eurostat/statisticsexplained/index.php/Unemployment_statistics [Accessed 10 October 2016].

Ferdinand, P., 2016. Westward ho- the China dream and 'one belt, one road';

Chinese foreign policy under Xi Jinping. International Affairs, 92(4):941-957.

Full text of Riga declaration, 2016. The Ministry of Commerce of the PRC, [online] 6 November. Available at: http://english.mofcom.gov.cn/article/ newsrelease/counselorsoffice/bilateralexchanges/201611/20161101651046. shtml [Accessed 20 November 2016].

Jacques, M., 2012. When China Rules the World. The End of the Western World and the Birth of a New Global Order. $2^{\text {nd }}$ Edition. London: Penguin Press.

Jakóbowski, J., 2015. China's foreign direct investments within the '16+1' cooperation formula: strategy, institutions, and results. Commentary, OSW Centre for Eastern Studies, [online] November. Available at https://muw.osw.waw.pl/ sites/default/files/commentary_191.pdf [Accessed 11 July 2016].

Kong, T., 2015. 16+1 Cooperation Framework: Genesis, Characteristics and Prospect. China-CEEC think-tank Network, [online] December. Available at: http://16plus1-thinktank.com/1/20151203/868.html [Accessed 1 March 2016].

Kissinger, H., 2014. World Order: Reflections on the Character of Nations

and the Course of History. London: Penguin. 
Lanteigne, M., 2013. Chinese Foreign Policy: An Introduction. 2nd Edition. New York: Routledge.

Le Chorre, P. and Sepulchre, A., 2016. China's Offensive in Europe. Washington: The Brookings Institution Press.

Long, J., 2014. Relations between China and CEE Countries: Development, Challenges and Recommendations. China Institute of International Studies, [online].Availableat:http://www.ciis.org.cn/english/2014-11/21/ content_7388215.htm [Accessed 10 January 2015].

Ministry of Foreign Affairs of the People's Republic of China, 2013. President Xi Jinping Delivers Important Speech and Proposes to Build a Silk Road Economic Belt with Central Asian Countries. Ministry of Foreign Affairs of the People's Republic of China, [online]. Available at: http://wnw.fmprc.gov. cn/mfa_eng/topics_665678/xjpfwzysiesgjtfhshzzh_665686/t1076334,shtml.

Ministry of Foreign Affairs of the People's Republic of China, 2013. Promote Friendship Between Our People and Work Together to Build a Bright Future. [online] 9 August. Available at: http://www.fmprc.gov.cn/mfa_ eng/wjdt_665385/zyjh_665391/†1078088.shtml [Accessed October 2016].

MFAPRC News Release, 2015. The Medium-Term Agenda for Cooperation between China and Central and Eastern European Countries. [online] 24 November. Available at: http://www.fmprc.gov.cn/ mfa_eng/zxxx_662805/t1318038.shtml [Accessed 2 October 2016].

NDRC News Release, 2015. Vision and Actions on Jointly Building Silk Road Economic Belt and 21 st-Century Maritime Silk Road. NDRC, [online] 28March. Available at:http://en.ndrc.gov.cn/newsrelease/201503/ †20150330_669367.html [Accessed 10 January 2017].

Overholt, W., 2015. One Belt, One Road, One Pivot. Global Asia, 10(3): 2-8. Poulain, L., 2011. China's New Balkan Strategy. Central Europe Watch, CSIS. 1(2): 1-7.

Rollande, N., 2015. China's New Silk Road. The National Bureau of Asian Research, [online] February. Available at: http://nbr.org/research/ activity.aspx?id=531 [Accessed 13 December 2015].

Shambaugh, D., 2013. China Goes Global: The Partial Power. New York: Oxford University Press. 
The Belgrade Guidelines for Cooperation between China and Central and Eastern European Countries, 2014. Ministry of Foreign Affairs of the People's Republic of China, [online] 17 December. Available at: http://www.fmprc. gov.cn/mfa_eng/zxxx_662805/t1224905.shtml [Accessed 4 February 2015].

Turcsányi, R., 2014. Central and Eastern Europe's courtship with China: Trojan horse within the EU? EU-Asia at a Glance. European Institute of Asian Studies, IAS Policy Paper, [online] January. Available at: http://www.eias.org/wp-content/uploads/2016/02/EU-Asia-at-aglance-Richard-Turcsanyi-China-CEE.pdf [Accessed 7 May 2015].

The World Bank, 2016?. Available at: hitp://databankworldbankorg/data/Niews/ Metadata/MetadataWidget.aspx? Name=GIN\%20index\%20/World\%20Bank\%20 estimate)\&Code=SI.POV.GNI\&Type=S\&ReaType=Metadata\&dalSelectedValue=SAU\&R eportD=43276\&Reportlype=Table (Accessed November 2016).

The World Bank, 2016? . Available at: http://databank.worldbank.org/data/reports. aspx?source=2\&type=metadata\&series=IC.BUS.EASEXQ (Accessed November 2016).

XU, Q., 2006. Maritime Geostrategic and the Development of the Chinese Navy in the Early 21 st Century. Naval War College Review, 59(4): 47-67.

Marsela Musabelliu (marsela.musabelliu@gmail.com) is a PhD candidate at Xiamen University, World Economy Department, School of International Relations. Her dissertation is focused on Chinese Investment in Central and Eastern Europe and particularly on the 16+1 cooperation mechanism. She graduated from the University of Milan (Italy) in Political Science and obtained a Master Degree in International Relations at the same university, with a focus on Diplomatic Law. She also holds another Master of Law in International Relations from Xiamen University with a thesis which analyzes Sino-Albanian Relations. Furthermore, she has 11 years of professional experience in international trade, holding the position of Procurement Manager for Asia in one of the largest retailers and wholesalers of consumer's goods companies in the Balkans. Her fields of research are Chinese foreign policy, China's outward foreign direct investments (OFDIs), 16+1, Sino-Albanian relations and the Belt and Road Initiative. 